\title{
Effect of polyphenols which extracted from green tea in reduce toxic effects of cadmium sulfate in rat's livers
}

\author{
Sa'adeya Ali Al-Gnami \\ Al-Qadisiyeauniversity, Collage of medicine veterinary,Department of Pharmacy
}

\begin{abstract}
This experimental was carried out in animal hosbital of veterinary medicine in Al-Qadisiyea university to investigate the positive role of polyphenols in liver protection from toxic effects of cadmium sulfate.twinty four of animals from femal rats were used the animals were divided to four groups(six animal/group) which are control group (given water and food only) and three of treatment groups, the first treatment group was given $50 \mathrm{mg} / \mathrm{L}$ from cadmium sulfate with drinking water,the second treatment group was given cadmium sulfate $(50 \mathrm{mg} / \mathrm{L})$ and $400 \mathrm{mg} / \mathrm{k} . \mathrm{g}$ of $\mathrm{B} . W$ from polyphenols, and the third treatment group was given polyphenols only $(400 \mathrm{mg} / \mathrm{kg}$ of B.W) the drenching was lasting for thirty days for all groups, all groups housed under same condition.The level of AST and ALT were measured in plasma.thehistlogical section of liver were examined The results of this study reveaeled to significant increase $(P \leq 0.5)$ level AST and ALT in first treatment group that was drenched cadmium sulfate compare with control group also the liver histological study was indicate damage in liver tissue resamble found sever congestion hemorrhage, necrosis of hepatocytes ,thrombi in the central vein, and fatty degeneration in contrast with control group .while, in second treatment group that was given polyphenols and cadmium sulfate the result shown to improve in liver tissue and significant decrease $(P \leq 0.05)$ in level of AST and ALT in compare with first treatment group and the results of this study indicated a significant decrease $(P \leq 0.05)$ in ASTand ALT in third treatment group that was given polyphenols only compare with control group and second treatment group
\end{abstract}

\section{Introduction}

Herbal medicine has been commonly used over the years for treatment and prevention of diseases and health promotion as well as for enhancement of the span and quality of life (1.2). Many drugs used in conventional medicine were originally derived from plants (3). Green tea ( camellia sinensis )is one of the most commonly consumed beverage worldwide. It's active components are reports to have several biological properties, including cancer chemoprevention, inti- inflammatory activities, antioxidant activity (4). The active phytochemicals in green tea are :-

1- pdyphenols (30-36\%), principally flavanols, more commonly known as catechins the predominant catechins are epigallocatechin - 3- gallate (EG CG) epicatechin-3- gallate (ECG), epigallocatechin (EGC) and epicatechin (EC). (5).

2- Xanthic bases (affeine and theophylline).

3- Essential oils

4- Proteins $(15-20 \%$ dry weight).

5- Carbohydrates (5 - $7 \%$ dry weight).

6- Vitamins.

7- Minerals and trace elements ( $5 \%$ dry weight ).

8- Lipids : As linoleic and linolenic acids, sterols as stigmasterol.

9-Volatile compounds: As aldehydes, alcohols, esters, lactones, hydrocarbons. (6).

Green tea is very rich in polyphenolic constituents which have high antiflammatory, antioxidant, and antimutagenic properties in various biological system (7).

Plolyphenols in green tea are potent antioxidants (8) and they have been linked with the hypothesis that their redox activities may confer specific health benefits(9). Polyphenols from green tea could be of special interest in the metabolic syndrome because epidemiologic observations and laboratory studies have shown that green tea has a variety effects including antioxidant and hypolipemic activities $(10,11)$.

Green tea polyphenols can scavage active oxygen free radicals cells produced in many systems and protect cells from damage induced by free radicals (12).

The purpose of this study was to investigate the protective effect of polyphenol against liver damage induced by cadmium SulFate. 


\section{Extraction of phenolic compound}

\section{Material and Methods}

The leaf of green tea was obtained from local market of Al-aadisyia city. Then dried and powdered, according to Gyon method(13)(200)gm of plant powder was weighted and added to (800)ml of $2 \%$ acetic acid and extracted, the mixture was left for 42 hours in an incubator at (50)c then filtered through filter paper to remove all the residual materials. The clear extracted solution treated with the same volumes of n.propand and then saturated with Nacl. The upper layer was separated by funnel, then dried at $45 \mathrm{c}$ using an incubator.

\section{Experimental animals}

Twenty-four femal Albino rats of wister strain of age(6-8 weeks) and weighting about (250 \pm 13 )gm were used for the experiment. These animals reared under controlled conditions. The period of this experimental was 30 days.

\section{Experimental design}

Animals were divided into four groups of six animals for each group

1- Control group : given distilled water for 30 days.

2- The first treatment group (T1) given (50 mg/L) of cadmium sulfatewith drinking water for 30 days

3- The second treatment group (T2) given $(50 \mathrm{mg} / \mathrm{L})$ of cadmium sulfate with drinking water, and orlly gavage (400 $\mathrm{mg} / \mathrm{kg}$ of B.W) of polyphenol for 30 days.

4- The third treatment group (T3) orally gavage (400 mg/kg of B.W) of polyphenol for 30 day.

\section{Blood and tissue collection}

At the end of the experimental period (30 days), the animals were sacrified and blood samples were collected directly into tubes and centrifuged at $300 \mathrm{rpm}$ for 20 minutes. The obtained serum was stored at $4 \mathrm{c}$ for estimation of AST and ALT. The liver was also quickly removed and washed with cold normal saline, cut and preserved in $10 \%$ neutral Formalin for the pathological studies for microscopy.

\section{- $\quad$ Estimation of AST and ALT}

AST and ALT were estimated according toAcolorimetric method by using kit (14).

\section{- Hitological examinations}

Liver tissues were cut in small pieces, placed in plastic cassettes, and immersed in neutral buffered Formalin for 24 hours. The fixed tissues were processed routinely, embedded in paraffin, sectioned, deparaffinized and rehydrated using the standard techniques(15).

\section{- Statistical Analysis}

The one way analysis of variance(ANOVA) was used for analysis of study results, and then Duncan's test $(\mathrm{P} \leq 0.05)$ was detected to compare between groups $(16)$.

\section{Results and Discussion}

The results obtained from this study showed a significant increase $(\mathrm{P} \leq 0.05)$ in AST $(65 \pm 1.88)$ and ALT (205 \pm 1.46$)$ enzymes (table1) in first treatment group (T1) that was administrated cadmium sulfate (50 $\mathrm{mg} / \mathrm{L})$ in contrast with control group, als this study revealed a significant decrease $(\mathrm{p} \leq 0.05)$ in AST $(50 \pm$ $2.25)$ and ALT $(179 \pm 4.29)$ in second treatment group (T2) that was administrated polyphenol $(400 \mathrm{mg} / \mathrm{kg} \mathrm{of}$ B.W) and cadmium sulfate $(50 \mathrm{mg} / \mathrm{L})$ comparing with first treatment group (T1). Also, this study seems to show a significant decreae $(\mathrm{p} \leq 0.05)$ in AST $(39 \pm 2.54)$ and ALT $(137.3 \pm 2.31)$ in third treatment group (T3) that was administrated polyphenols comparing with control group and second treatment group(T2) (table 1).The histological study for liver tissue of first treatment group showedsever hemorrhage ,congestion, Necrosis of hepatocytes. Also there is mild infiltration of inflammatory cells ofliver tissue(figure 3) andLarge thrombi in the central vein, fatty degeneration (steatosis) in the hepatocytes (hepatocytes appear as signet - like shape)(figure 4). compared with control group(figure 1,2). And there is improved in liver tissue of second treatment group that was administrated polyphenol and cadmium sulfate, it observed there is normal hepatic architecture (figure 6,7) Also, this study indicated normal hepatic architecture of liver tissue and normal hypatocytesin third treatment group that was drenched polyphenol.(figure 8)

The liver is the major organ responsible for metabolism of drugs and toxic chemicals, therefore it is the primary target organ for nearly all toxic chemicals toxins break down physicals barriers and cause tissues damage (17). 
¿Effect of polyphenols which extracted from green tea in reduce toxic effects of cadmium sulfate ...

Nguyen etat., (18) found that is administration of cadmium caused cytotoxicity in hepatocytes and showed an increase in reactive oxygen species and reduce the activity of antioxidant enzymes such as superoxide dismutase and catalase (19).

Free radicals reduce goltathion in liver tissue, bind to the thiol group oxidation of cytochromes, reduce of calcium, break down DNA, and oxidation of faty acid $\backslash+\mathrm{s}$ (polyenic) that is found in plasma membrane of liver cell $(20,21)$. This eventually leads to damage the liver tissue and this result agree with Markovic and james(22).

AST and ALT enzymes are located in various structure of the cells AST concentration mainly in liver, heart, skeletal, muscles, red blood cells, and kidney (23). ALT found with high concentration in liver and found with low concentration in pancrease and skeletal muscle(24) increase in activity of ALT and AST is sensitive sign of impaired organs membrane and well indicate disturbance in the structure and integrity of cell organelles, like endoplasmic reticulum and membrane transport system $(25,26)$. Therefore, the increase in AST and ALT in rats that drenched cadmium sulfate may be returned to increase lipid peroxidation and subsequent degradation of biomembranes, the permeability of the plasma membranes was severely affected and may lead to leakage of AST and ALT and increasing in their activities in the serum. Polyphenols are classified as antioxidants which mean they can protect cell and body chemicals against damage caused by free radicals $(27,28)$ therefore administration of polyphenols lead to a significant decrease in AST and ALT and improved in liver tissue comparing with group that administered cadmium sulfate.

Several studies have indicated that polyphenol play important role in improved level of antioxidant enzymes such as Glutathione peroxides, catalase, Glutathione reductase, Glutathione transferase, superoxide, dismutase (29). These enzymes function to inhibit activity of free radicals.

Heshametal.(30) recorded that Gultathion peroxidase plays a central role in the defense against oxidative damage and toxins. Also, some studies indicated that increase activity of superoxide dismutase in serum are implicated in cellular protection against reactive oxygen species(29,31).

Also found that polyphenols inhibits lipid peroxide formation(32), for this reason polyphenol may be improved liver tissue and decreased AST and ALT in plasma.

Table(1) effect of polyphenol on AST and ALT level of female wister rats treated with cadmium sulfate

\begin{tabular}{|c|c|c|}
\hline $\begin{array}{l}\text { Test } \\
\text { Group }\end{array}$ & AST & ALT \\
\hline Control & $52.16 \pm 1.52^{A}$ & $152.66 \pm 3.10 .^{A}$ \\
\hline $\begin{array}{l}\text { Treatment } \\
\text { (T1) }\end{array}$ & $65.0 \pm 1.88^{B}$ & $205.0 \pm 1.466^{\mathrm{B}}$ \\
\hline $\begin{array}{l}\text { Treatment Second } \\
\text { (T2) }\end{array}$ & $50.0 \pm 2.25^{A}$ & $179.0 \pm 429^{C}$ \\
\hline $\begin{array}{l}\text { Third treatment } \\
\text { (T3) }\end{array}$ & $39.0 \pm 1.25^{c}$ & $137.33 \pm 2.31^{\mathrm{D}}$ \\
\hline
\end{tabular}

Number=average \pm standard error (S.E)

Different litters $=$ significant differences $(\mathrm{P} \leq 0.05)$

$\mathrm{T} 1=$ given cadmium sulfate $(50 \mathrm{mg} / \mathrm{L})$ with drinking water for 30 day

$\mathrm{T} 2=$ given cadmium sulfate $(50 \mathrm{mg} / \mathrm{L})$ with drinking water and orally gavage polyphenol $(400 \mathrm{mg} / \mathrm{Kg}$ of B.W)for

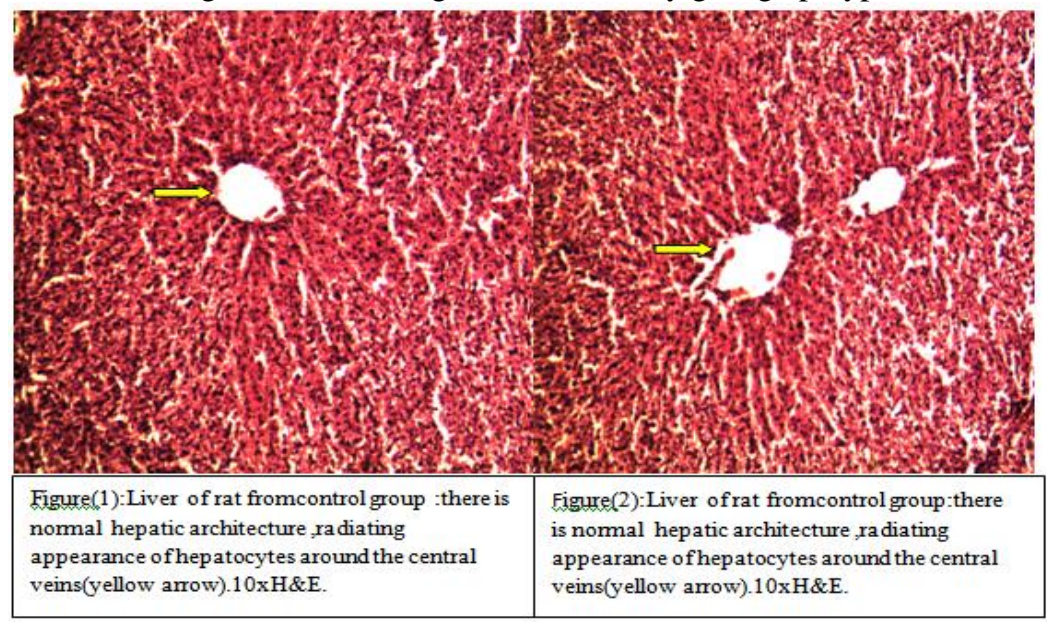

30 day $\mathrm{T} 3=$ orally gavage polyphenol $(400 \mathrm{mg} / \mathrm{Kg}$ of $\mathrm{B} . \mathrm{W})$ for 30 day 

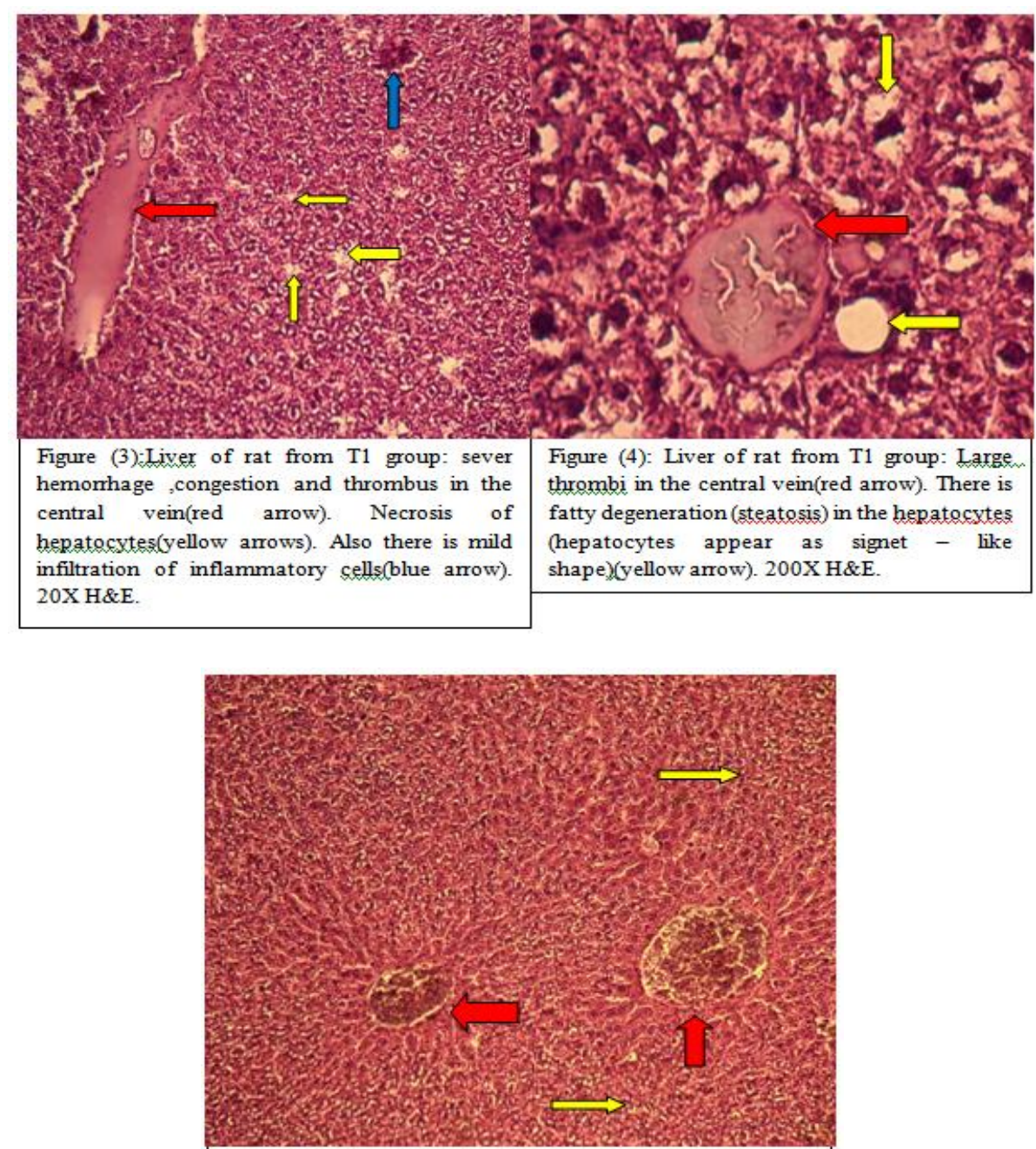

Figure (5)-Liver of rat from T1 group: sever congestion in the central vein(red arrows). Necrosis and fatty degeneration of hepatocytes(yellow arrows) . 20X $\mathrm{H} \& \mathrm{E}$.

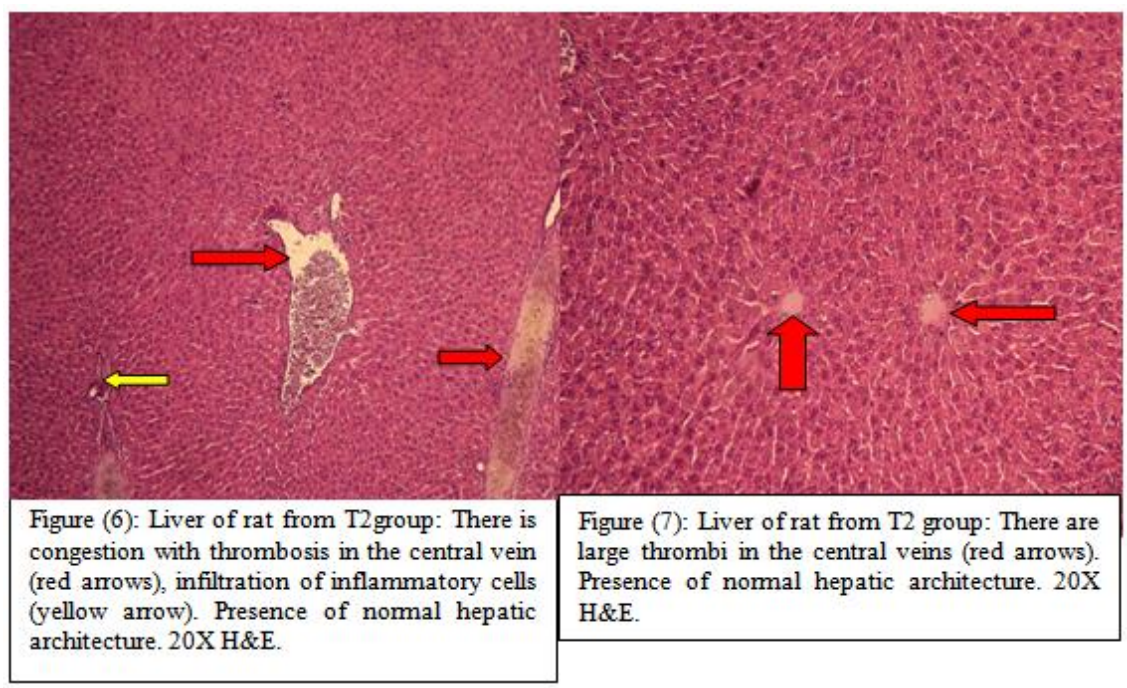




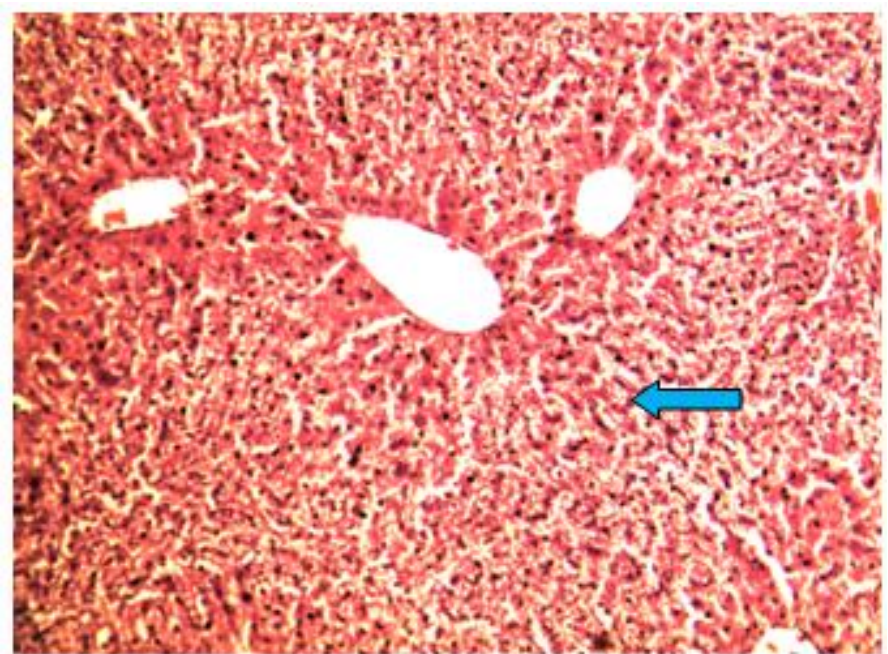

Figure(8):Liver of rat fromT3 group:there is normal hepatic architecture, radiating appearance of hepatocytes around the central veins(blue arrow).10xH\&E.

\section{Refernces}

[1]. Ernst , E. ; Schmidt , K . ; and wider B . ( 2005 ). CAM Research in Britain : the last 10 years . complement therclinpract . 11 : 17 20 .

[2]. Ribnicky D . M , ; Poulev, A . ; Schmidt , B .; Cefalu , W . T .; and Raskin , I . supplements for human health : a view from the nih botanical research centers evaluation of botanicals for improving human health . Am J clinNutr . $87: 472 \mathrm{~s}-5 \mathrm{~s}$

[3]. Oreagba , I . A . ; Oshikoya , K . A . ; and Amachree, M . (2011). Herbal medicine use among urban residents in lagos , Nigeria . V (11) .

[4]. Yang, C , S . ; chung, I . Y . ; Yang, G . ; chabra , S . K and Lee, M . J . ( 2000). Tea and Tea polyphenols in cancer prevention , J . Nutr $130: 472 \mathrm{~s}-8 \mathrm{~s}$

[5]. Figueiroa, M . S .; Cesar Vieira, J . S . ; Leite , D . S .; Andrade filho , R . C . O . ; Ferreira .; F . ;Gouveia , P . S . ; Udrisar , D . P. ; and wanderley, M . I . (2009). Green tea polyhenols inhibit testosterone production in rat leydig cell, Asian Journal of Andrology $11: 362-370$.

[6]. Costa , L . M . ; Gouveia , S . T ;Nobrega , J . A . (2002) . Comparison of heating extraction procedure for Al , Ca , Mg and Mn In tea samples, Ann Sci $18: 313-318$.

[7]. Kanwar , J . ; Taskeen , M . ; Mohammad , I . ; Huo , C . ; Chan . T . H .; and Dou , O . P . (2012) . Recent advances on tea polyhenols . front Biosci (EliteEd ) $4: 111-131$

[8]. Leihton , F . ; Cuevas , A . ; and Guasch , V . (1999). Plasma polyphenols and antioxidants , ovidative DNA damage and endothelial function in a diet and wine intervention study in humans . Drugs ExpClin Res $25: 133-141$

[9]. Scalbert , A . ; Manach , C . ; and Morand , C . (2005 ). Dietary polyphenols and the prevention of diseases . Crit Rev Food SciNutr $45: 287-306$

[10]. Mckay, D . L . ; Blumberg, J . B .(2002). The role of tea in human health : an updata . Jam collNutr $21: 1-13$

[11]. Coimbra , S .; Castro E . ; and Rocha - Pereira . P ( 2006). The effect of green tea in oxidative stress . ClinNutr 25 : 790 - 796.

[12]. Guleria , R. S.; Amita , J . ; Tiwari . V . ; and Mishra , M . K . (2006). Protective effect of green tea extract against the erythrocytic oxidative stress injury during mycobacterium tuberculosis infection in mice . Mol . Cell Biochem , $236,173-181$.

[13]. Gayon , T , A. ( 1972 ). Plant phenolic . Olive and Boyed . Rd In boura . pp 254.

[14]. Reitman , S . and frankel ., S . A. (1957). Acolorimetric method for the determination of serum Glutamic oxaloacetic and Glutamic pyrovic Transaminase .Am . J . clin . Path , 28, 6-63.

[15]. Luna , L . G . (1968). Processing of tissue , histologic staining methods of the aemed forces institute of pathology . 3rd Ed . Mc Graw Hill book comp . London, New York, Toronto, Sydney . pp : $12-31$

[16]. Shiefler, W . C. (1980). Statistics for biology science . 2nd Edition . Adison, Wesley , Pub . co . London Amesterdam . pp. 121 .

[17]. Bissel , D . M. , G . J . Gores , D . L . Laskin and J . H. Hoorhagle , (2001 ). Drug indoced liver injury : Mechanism and Systems Hepatology $33: 1009-1013$

[18]. Nguen , K . C . ; willmore , W . G .; and Tayabali . A . F . (2013 ) . Cadmiun Telluride Quantum Dots cause oxidative stress leading extrinsic and intrinsic apoptosis in hepatocellular carcinoma HepG2 cells .Toxicology Apr 5 : 306 : 114 - 23 . doi :10 . $1016 / \mathrm{j}$ Toxi

[19]. Ferrari , C . K . B . (2000). Free radicals, lipid peroxidation and antioxidnts in apoptosis : implications In cancer , cardiovascular and neurological diseases, Biol ., Bratislava , 55 (6) : $581-590$

[20]. Elliot , R . H . and strunin , L . (1993 ). Hepatotoxicity of volatile anaesthetics . British Journal of Anaesthaesia , 70 , 339 - 349

[21]. Parke , D . V . (1994). The Cytochromes P45 and mechanisms of chemical carcinogenesis, environmental health perspectives , $852-853$

[22]. Markovich . D . and James , K . M . (1999). Heavy metals mercury , cadmium , and chromium inhibit the activity of the mammalian liver and kidney sulfate transporter sat - 1.Toxicology and applied pharmacology , $154: 2: 181-187$

[23]. Bennett , J . C ; and Plum , F . (1996) . Textbook of Medicine . 20thed . , 1 . w .

[24]. Martein , D . W . ; Mayes , P . A .; Rodwell , V . W. and Granner , D . K . (1985 ) . Hrper's Review of Biochemistry . 20thed ., Lange Medical

[25]. Fudge , A . M . (1997) Avian clinical pathology hematology and chemistry . in : Avian medicine and surgery . aitman , R . B .; Clubb, S . I .; Dorrestein , G.m .; Quesenberry , K . (eds ) W .B .; saundersco ., philadebhia , pennsylvania pp : 142 - 157 .

[26]. Fonte, R ., Agosti , A .; scafa , F. and Candura , S . M. (2007). Anaemia and abdominal pain due to occupational lead poisoning haematol ., $92: 13-14$ 
[27]. Williams , R . J .; Spencer , J . P ., and Rice - Evans , C . (2004 ). Flavonoid : antioxiidonts or signaling molecules . free radical biology and medcine 36(7) : $838-49$ - doi $: 10.1016 / \mathrm{j}$. freeradbiomed .

[28]. Felicien, B . (2008) Polyphenol antioxidants in red win ( http : / www . frenchscout . com / polyphenots ).

[29]. Hesham , N .; Moemen, L.A.; and Abu Elela , M.H. (2008). Studing the levels of mlondialdehyds and antioxidand Parameters in normal and abnormal humn seminal plasma . Aust J Basic and App 1 . scr . 2 ( supp; 3 ) : 773 - 778 .

[30]. Skrzydlewska, E. Ostrowska ,J. ; Farbiszewski , R .; and Michalak , K . (2002). Protective effect of green tea against lipid peroxidation in the rat liver blood serum and the brain . phytomedicine $9: 232-238$

[31]. Negishi-H ; xu , J .; Ikeda .; Njelekela , M. ; Nara, Y .; and Yamori, Y . . (2004 ). Black and green tea polyphenls attenuate blood pressure increas in stroke - prone spontaneously hypertensive rats . J . Nutr . 134:38-42.

[32]. Stangl , V . ; Lorenz , M .; and stangl , K . ( 2006 ). The role of tea and Tae flavonoids in cardiovascular health . MolNutr . food Res. $50: 218-228$. 